\title{
Work and Employment Relations in a Globalized World: The Emerging Texture of Transnational Labour Regulation
}

\author{
Ludger Pries, Rubr University Bochum, Germany \\ Martin Seeliger, Max-Planck Institute for the Study of Societies, Cologne, Germany
}

\begin{abstract}
While globalization has led to what can - with reference to Karl Polanyi - be referred to as a disembedding of the labour market from its nationally segmented settings, recent decades bring about a development identifiable as a 'countermovement'. As the text shows, drawing on the example of European Works Councils and International Framework Agreements, this process of 're-embedding' takes place through a network of different measures of labour regulation. It is for this reason that establishing a relational perspective on cross-border phenomena in the field of labour relations can count as a central future aim in this strand of research.
\end{abstract}

\section{KEY WORDS}

cross border research, European works councils, globalization, international framework agreements, labour regulation

\section{Introduction}

'Workers of the world, Unite!' - viewed from today's perspective and the context of the challenges brought about by globalization, the rallying cry of proletarian internationalism proclaimed by Karl Marx and Friedrich Engels in 1848 implies an optimistic notion of the possibilities for cross-border coordination of workers' interests, leading to a classless and stateless world society. History has so far not proved this revolutionary prediction right. 'Real socialism' collapsed, and the logic of markets spread over the world. Many scholars of international labour studies therefore are sceptical about the question of whether collective regulation of work and employment across borders could work and have a future. Increased international competition and globalized value chains have caused shifts in patterns of labour regulation in most industries and countries. Mainly, an erosion of national labour regulation regimes is diagnosed as an effect of almost unregulated international competition, value chains and trade - transnational mechanisms or even a global governance of labour regulation by most scholars in the field is seen as wishful thinking. In this paper it is argued that during the last twenty years or so an institutionalising texture of transnational labour regulation emerged and strengthened. This has 
to be understood as a way to restrain the logics of markets as well as of corporate and national interests and to institutionalise the logics of minimum standards, collective actors and civil society.

Since the interrelation of economy and society over time has always been at the core of sociological interest (Spencer 2003; Weber 2001; Durkheim 1984), insights from historical approaches to the development of this relationship are available within a rich instrumental set of different sociological perspectives. Here, for the second half of the twentieth century contemporary diagnoses and perceptions point at the increasingly dynamic character of this interplay, which leads to new uncertainties for individual as well as collective and corporate actors (Cohen and Kennedy 2000; Beck 1999; Hann and Keith 2009). In their study on 'labour in the age of insecurity' Webster et al. (2008) propose a perspective on the impact of globalization on local realities of work and employment, deploying the concept of market embeddedness, which was originally introduced by Karl Polanyi in the 1940s. According to Polanyi the dynamics of modernization are constituted through an interplay of the market and other institutions of economic coordination, competing as complementary principles to organize the production and distribution of goods and services. A developmental model which can roughly be derived from Polanyian thought unfolded in the course of subsequent general academic discussions. In this vain, economic globalization is understood as a partial 'disembedding' of nationally segmented markets and of production systems structured by national institutions. Many authors hold that this economic globalization led to a 'neoliberal' global logic of competition, value chains, production and trade (e.g. Altvater and Mahnkopf 1997; Burawoy 2010; Webster 2010), which is almost unbound from any kind of institutionalised regulation and control.

In line with an institutional approach and based on empirical evidence from meso-level studies on global value chains, production models and business models (e.g. Pries and Dehnen 2009; Ruigrok and van Tulder 1995; Spatz and Nunnenkamp 2002; Sturgeon and Florida 1999; Whitley 1992), this paper emphasizes that tendencies of global disembedding of economy from societal regulations and norms are accompanied by tendencies of re-embedding and reinstitutionalising through the search for new regulative arrangements. While on the one hand the logic of liberal market coordination of action and resources has grown, an increasing entanglement of mechanisms, levels and collective actors of labour regulation is emerging as crossborder texture of work and employment regulation (Pries 2010). Accordingly, emerging measures of cross-border labour regulation can be understood as tendencies to re-embed economic relationships, which have been tossed away from their former national settlements. Based on the Polanyan concept of dis-embedding and re-embedding and on the neo-institutional world polity approach of John Meyer it will be argued that during the last decades and in parallel with globalisation of capitalism there developed a multitude of old and new dynamics of cross-border labour regulation such as workers' world commissions in international companies, Global Union Federations, Grassroots' Campaigns, European Works Councils, International Framework Agreements, Multinational Guidelines, Core Labour Standards, or Global Compacts. Such mechanisms have been analysed and discussed mainly as singular logics of cross-border labour regulation, but not in their complex interplay. Consequently, almost all of these elements of cross-border labour regulation were stated as ineffective or weak or useless for recapturing and reembedding global capitalism. Such a view falls short in the same way as if the strength and 
functions of the single parts of the ecological entanglement of a jungle were evaluated bit by bit in an isolated manner.

For example, an International Framework Agreement (IFA) in place in one specific multinational company might work where there are strong collective promoters at the company level and where social movement activists use the OECD-Multinational Guidelines for submitting queries at the corresponding National Contacts Points. The complementary densification of labour regulation measures emerges as a cross-border network texture with reference and in relation to various actor groups as well as social, political and economic structures beyond the territorially bounded power-frame of a single nation-state. While such measures of international labour regulation seem relatively weak when looked at in isolation from each other, a consideration of their interplay promises to provide a much more fruitful insight on the matter: By drawing on the results of empirical research conducted on European Works Councils as well as on International Framework Agreements, the paper will empirically base the theoretical approach proposed above.

After briefly sketching out the implications and challenges for international labour regulation brought about by globalization, the paper draws on the idea developed earlier (Pries 2010), according to which single cross-border mechanisms of labour regulation have to be understood as part of an emerging texture of various entangled and often complementary measures which (often in an unintended way) strengthen a framework of norms and rules suitable to creating order in the challenging field of the international economy. Drawing on the example of the emerging institutions of European Works Councils and International Framework Agreements, this basic idea of an emerging cross-border texture of labour regulation will be developed in the following two sections. Finally, we will sum up our findings by reflecting on desiderata for further research.

\section{Labour Regulation in a Globalized Economy}

Economic globalization (e.g. Seidmann 2007) made processes that were once nationally segmented constellations of labour regulations subject to increasing international competition. According to many scholars, this led to an erosion of traditional constellations of labour regulation, which were usually framed by the institutional setting of the nation-state. As EgelsZanden (2009: 3) states, 'industrial relations systems have historically been embedded in a context of national tripartistic arrangements, negotiated by actors engaged in ongoing relationships with each other'. According to Burawoy (2009: 90), the United States took a leading role in this process of economic 'dis-embedding': 'It had its epicenter in the United States. Beginning in the mid-1970s, the turn to a market economy led to the decimation of national industries and its labour movements as US industrial capital fled to greener pastures.' ${ }^{1}$ Besides the general axiom that economic internationalization actually has taken place, ${ }^{2}$ another widely shared assumption points at the structural weakening of the bargaining power of workers and their collective representatives in negotiations with management. Through the development of what could be called a global market for labour, ${ }^{3}$ the supply side (i.e. the workers) is pressured into lowering their exchange expectations: 'It is a commonplace that, in the past 30 or so years, the transnationalisation of production from the global North to the global South has played a major role in shifting power away from workers to employers' (Wells 2009: 567). 
This had led scholars to take on a position which has become known as the so-called raceto-the-bottom-thesis, which is applied not only in the field of social policy but also in connection with labour regulation within an internationalizing world economy: 'As states decline, so do workers' rights' (Tilly 1995: 21). If we thus understand this problem against the backdrop of state-centred policy-approaches, which were typical for the $20^{\text {th }}$ century, the absence of a superordinate Leviathan, the international landscape of collective regulation measures might appear to be a neoliberal desert, a characterisation which we know from the early 1980s 'end time' genre (Mad Max, etc.). ${ }^{4}$ According to Thomas (2010: 1) 'globalization processes have produced a downward pressure on labour standards that neither nationally based labour laws nor international institutions such as the International Labour Organization have been able to effectively counter.' As Koch-Baumgarten (2006: 208) states, the establishment of a sufficiently institutionalized industrial relations system in a corporatist sense on a global or at least supranational (e.g. European) level seems improbable not only to scholars who research the topic. While traditional corporatist patterns do not seem to be rigidly transferable to a supranational level, it would be far-fetched to assume that there are no concepts of labour regulation to cope with the effects of market liberalization. 'Thus, unions and other civil society organizations have pushed for new approaches to the regulation of labour standards, creating pressures for the emergence of new forms of transnational labour rights regulation' (ibid: 1). While management induced measures were often directed at weakening the bargaining power of workers through the introduction of competitive elements in the cross-border coordination of labour policy, strategies of workers' representatives were manifold and sometimes contradictory. Meanwhile, some union and company-based workers' representative bodies (like works councils) concentrated on defending employment and preventing outsourcing, while others proactively fought for a sustainable and socially acceptable restructuring process. Simultaneously, some collective actors focused on their local, regional or at most national territory, and still others invested a lot of energy in networking at a transnational level by accumulating social capital and building alliances with other political actors, such as social movements or government representatives:

'As a consequence of TNCs' growing flexibility and capacity to shift production from one country to another, trade unions began to attempt to create a social framework for the global economy in order to bridge the growing gap between TNCs' strategic options, which transcend national borders, and their own limited capacity to act, since they are largely circumscribed by national boundaries'. (Telljohan 2009: 5)

It is exactly this emerging constellation into which measures of cross-border labour regulation are being brought about by a spectrum of actors which reaches beyond the classical triangle of (nationally segmented) states, capital and labour representatives. Looking at the broader landscape of cross-border labour regulation, various forms of such regulative measures can be identified (see Pries 2010: 157). Firstly, on a global level wide-ranging minimum standards, such as the ILO-core norms, constitute an ethical framework, suitable to formulate basic requirements for working and employment conditions around the globe. While chances to control a company's compliance with the provision of such basic rights seem relatively weak, the general opportunity to relate to such frameworks can serve as a useful point of reference for 
labour representatives in calling for decent working conditions and to define new milestones of legitimacy - something corporate actors and companies have to consider and take seriously.

In this context, the notion of legitimacy goes far beyond formal-legal rights. It points at the general embeddedness of economic action within a broader societal framework. Here the neoinstitutional concepts of organisational fields and of world polity as well as the Polanyan idea of re-embedding come in. Neo-institutionalism argues that organisations adapt their structure and strategy to the institutionalized expectations of their 'organisational field' - even sometimes against the specific organisational imperatives of rationality and efficiency (Meyer and Rowan 1977; Powell and DiMaggio 1991). Concerning international companies as profit organisations this means that - in order to legitimise themselves in their multi-dimensional organisational field of stakeholders and shareholders - they actually take into consideration the perceived legitimacy expectations of the organizational environment. Adaption to these legitimate expectations can be induced by mimetic (imitating, copying, representing), normative (following professional rules and standards) and coercive (laws, legal pressure etc.) mechanisms. Insofar as perceived legitimate expectations of how to act in an organizational field get habitualised, typified and symbolically sedimented, they are institutionalized within particular organizational fields.

Taking this basic idea of neo-institutional thinking, the very different mechanisms of transnational labour regulation could get institutionalized and build parts of complex transnational organizational fields, in which states, companies, international organisations etc. as corporative actors and other groups of collective actors perceive social reality and define strategies of action according to the institutionalised patterns of legitimate social relations and behaviour. A crucial question then is, to what extent different mechanisms of collective and transnational labour regulation are perceived and work as institutionalised patterns that forge the behaviour of all actors in the organisational field. For the area of science and education Meyer (2003) argued that some social institutions like a public and compulsory system of primary and secondary education established world-wide. Therefore he speaks of a world polity as consisting of global social institutions that - although not necessarily fully implemented all over the world - represent a set of rules, values and mechanisms accepted globally as legitimate. In a similar line it could be argued that since some two decades or so an institutionalised framework of transnational labour regulation is emerging.

As pointed out by Karl Polanyi, the challenges of marketization are met by societal reactions, which he identifies as 'countermovements,' enacted by social actors trying to cope with the implications of these processes. The interplay of the expanding market and the societal reactions can thus be understood as 'the action of two organizing principles in society, each of them setting itself specific institutional aims, having the support of definite social forces and using its own distinctive methods' (Polanyi 1957: 132). Taking up Polanyi's description of the societal development of market-disembedding and market re-embedding, it is possible to say that waves of commodification and de-commodification of labour can be encountered at different points in history (ibid; also Burawoy 2010: 307). Due to that, increased international mobility of capital measures of labour regulation that once operated in nationally bounded conditions are no longer strong enough to protect labour from threats of relocation or the top-down implementation of poor working standards in countries or regions where labour representatives have low bargaining power. By not only focussing on the impact of globalization on labour regulation, but also extending his approach to the fields of nature and money, Burawoy (2010: 307) comes to a 
conclusion which appears less optimistic than the prospects of a re-embedding movement. Primarily focussing on the latter two (commodification of money and nature), he states that:

' $[S]$ o far the third wave has delivered new and wild forms of the commodification of money, turning it from a medium of exchange into a tool of profit making, based in derivatives, futures, and securitization of loans, and operating through hedge funds largely outside the control of states'. (ibid: 307)

Many scholars similarly have argued that not only money and nature but also labour is experiencing 'wild forms of commodification'. As Burawoy notes with regard to the application of the Polanyian concept of 're-embedding', it is the global starting point which a countermovemet in the abovementioned sense would need to take (ibid 2010: 311). With reference to the objections of Burawoy, Webster (2010: 386) criticizes the 'use of dichotomies in framing the local versus the global' (also see Lambert 2010 as well as the other contributions from the controversy in the same issue [3/2010] of Global Labour Journal). As he further argues, neither methodological nationalism and the classical focus on the triad of state, employer associations and unions, nor a global perspective are able to capture what is going on in the field of transnational labour regulation (Pries and Seeliger 2012). Instead, what can be detected as potentially re-embedding transnational labour regulation depends on the perspective taken.

As demonstrated in Table 1, a broad range and scope of different measures and initiatives of regulating conditions and relations of work, employment and participation at a transnational level can be identified, which have been introduced by a broad variety of collective actors involved. Besides international organisations like the ILO and the global employee and employer associations, European Works Councils emerged to coordinate measures of employee representation beyond the shop-floor and national level. A further important point lies in the appearance of additional and new actors putting forward an agenda of workers' rights. Social movement activities like the 'Clean Clothes Campaign' (Balsiger 2010) led to new rules of behaviour in corporate business organizations. Furthermore, supra-national collective and corporative actors more and more try to put forward common frameworks of regulation, such as the OECD-Multinational Guidelines (OECD 2008; OECD Watch 2012). 
Table 1: Types of Transnational Labour Regulation

\begin{tabular}{|c|c|c|c|c|}
\hline $\begin{array}{l}\text { Type/logic of } \\
\text { regulation }\end{array}$ & $\begin{array}{l}\text { Geographic- } \\
\text { material reach }\end{array}$ & $\begin{array}{l}\text { Main actors } \\
\text { involved }\end{array}$ & $\begin{array}{l}\text { Enforcement, } \\
\text { control capab. }\end{array}$ & Examples \\
\hline Minimum standards & $\begin{array}{l}\text { Global, universal, } \\
\text { status of human rights }\end{array}$ & $\begin{array}{l}\text { United Nationes/ ILO, } \\
\text { unions, employer } \\
\text { assoc. }\end{array}$ & $\begin{array}{l}\text { Ratification, } \\
\text { Monitoring, blaming, } \\
\text { no legal sanctions }\end{array}$ & $\begin{array}{l}\text { ILO core conventions } \\
\text { No. } 29,87,98,100 \\
105,111,138,182\end{array}$ \\
\hline $\begin{array}{l}\text { Supranational } \\
\text { regulation }\end{array}$ & $\begin{array}{l}\text { Group of nation states, } \\
\text { complex issues }\end{array}$ & $\begin{array}{l}\text { Supranational bodies, } \\
\text { nation states, } \\
\text { international orgs. }\end{array}$ & \begin{tabular}{|l|} 
National legislation, \\
Supranational Court of \\
Human Rights
\end{tabular} & $\begin{array}{l}\text { European Unjon: } \\
\text { European Works } \\
\text { Councils }\end{array}$ \\
\hline $\begin{array}{l}\text { International } \\
\text { Framework } \\
\text { Agreements }\end{array}$ & $\begin{array}{l}\text { Collective bargaining } \\
\text { issues, organisation/ } \\
\text { branch wide }\end{array}$ & $\begin{array}{l}\text { Global Union } \\
\text { Federations, interna- } \\
\text { tional companies }\end{array}$ & $\begin{array}{l}\text { Good will declaration } \\
\text { no legal enforcement }\end{array}$ & $\begin{array}{l}\text { Volkswagen, DC, } \\
\text { Leoni, Arcelor, EADS, } \\
\text { PSA, Renault etc. }\end{array}$ \\
\hline Labeling, certifications & $\begin{array}{l}\text { Global, product or } \\
\text { organisation related }\end{array}$ & $\begin{array}{l}\text { Producer, consumers, } \\
\text { labeling/certif. orgs. }\end{array}$ & $\begin{array}{l}\text { Consumer decisions, } \\
\text { producers' image, no } \\
\text { accreditation }\end{array}$ & $\begin{array}{l}\text { Fair Trade, SA 8000, } \\
\text { DJSGI, Flower Label }\end{array}$ \\
\hline $\begin{array}{l}\text { Multinational } \\
\text { guidelines }\end{array}$ & $\begin{array}{l}\text { All companies with } \\
\text { headquarters in } \\
\text { signing nation states }\end{array}$ & $\begin{array}{l}\text { International orgs., } \\
\text { companies, national } \\
\text { agencies }\end{array}$ & $\begin{array}{l}\text { National reports, } \\
\text { blaming }\end{array}$ & $\begin{array}{l}\text { OECD multinational } \\
\text { guidelines }\end{array}$ \\
\hline Voluntary declarations & $\begin{array}{l}\text { Public opinion space } \\
\text { of internat. comp. }\end{array}$ & $\begin{array}{l}\text { Companies, media, } \\
\text { independent } \\
\text { monitoring orgs. }\end{array}$ & $\begin{array}{l}\text { Image, public relations } \\
\text { value, monitoring } \\
\text { reports }\end{array}$ & $\begin{array}{l}\text { Global Compact, } \\
\text { Corporate Social } \\
\text { Responsabilty }\end{array}$ \\
\hline $\begin{array}{l}\text { Campaigns } \\
\text { Public blaming }\end{array}$ & $\begin{array}{l}\text { Limited in time and } \\
\text { issue }\end{array}$ & $\begin{array}{l}\text { NGOs, media, public } \\
\text { opinion }\end{array}$ & $\begin{array}{l}\text { Discursive regulation } \\
\text { blaming }\end{array}$ & $\begin{array}{l}\text { Nestle, BS-Shell/Brent } \\
\text { Spa }\end{array}$ \\
\hline
\end{tabular}

Source: Authors' own elaboration

The crucial argument to develop here is that looking at each of the different types or logics of labour regulation as isolated mechanisms will easily lead to underestimating the actual impact and potential regulatory power of the mechanism. For instance, ILO minimum standards as fixed in the eight core conventions signed by the majority of all states worldwide will have almost no effect on work and employment conditions if at the local or national level there are no strong collective actors (whether state agencies, social movements, consumer organisations, unions etc.) promoting them. European Works Councils, although equipped with a legal basis of information and consultation rights at the European level, will hardly have any regulatory effect if there are no national representatives, unions and managers at the local, national and European level engaged in the logic of regulation. In general, the density of the actual transnational network texture emerges from the interplay of various different types of cross-border labour regulation. Unions or union federations might provide logistical support for monitoring initiatives or the capacity building of experts involved in social movements (Zajak 2009). Country-support and loans granted by the International Monetary Fund or the technical assistance of the World Bank might be made conditional on the nation-state's compliance with the global ILO core conventions. The actual dynamics of the OECD multinational guideline may depend on the engagement of social movements, NGOs, unions or states in controlling for the basic principles and reporting failures to the National Contact Points. In the following paragraph, the argument of the entanglement of these different transnational regulation mechanisms will be developed by drawing on the examples of European Works Councils and International Framework Agreements as parts of the broader transnational network texture. It is a politically important and scientifically 
crucial question under which conditions these different mechanisms work in which ways and with which outcomes. To understand their dynamic character, which distinguishes them from the classical patterns of national tripartite negotiations in the next two sub-sections the argument of an emerging network-texture of transnational labour regulation will be developed, drawing on the two examples of typical measures used in cross-border labour regulation: European works councils and International Framework Agreements.

\section{EUROPEAN WORKS COUNCILS}

The general directive on the introduction of European Works Councils (EWCs) was passed by the European Council of Secretaries on the $22^{\text {nd }}$ of September 1994 after circa ten years of ongoing discussions and prior attempts. It required the national governments which had backed the EWC-directive ${ }^{5}$ to create the legal basis for the introduction of EWCs within their states. The respective law in Germany (EWCL) was passed on the $28^{\text {th }}$ of October 1996 by the parliament. All companies with locations in at least two EU member states, each with at least 150 employees, and which had more than 1,000 employees distributed amongst EU member states, can institute a $\mathrm{EWC}^{6}$ on the basis of an agreement between a 'special bargaining committee' and European business management. In 2006 the ETUI-EWC database registered 773 EWCs in a total of 2,204 companies that would qualify for such a council. ${ }^{7}$

EWC regulation typically distinguishes three periods of EWCs. The first phase runs from the mid-1980s to 1994, and was a time when voluntarily agreed-upon employee informationand consultation organs were created. In this period 49 EWCs were created in 46 companies (Kerckhofs 2003:15). The second phase reaches from the period of the passage of the EU directive in September 1994 to its transformation into national law in September 1996. During this phase a number of so-called 'voluntary agreements' were reached on the basis of Article 13 of the EWC directive. As these did not necessarily have to accord with the procedure laid down by the directive and it was possible to deviate from the envisaged design, many companies were interested in grabbing the opportunity to reach a voluntary agreement on the procedure of information and consultation before the directive took effect (Hoffmann 1997:120; Lecher et al 2001: 194). During this 'bargaining under the shadow of the law' the number of agreements grew rapidly. Almost 400 so-called Article 13 agreements were finalised (see also Kerckhofs 2003). The third, so-called Article 6 phase refers to the period after the September 1996 implementation of the directive in national law, and with it the institution of EWCs according to 'standard legal procedure'.

In the expanding social science research on EWCs completed since the second half of the 1990 s very different theses on the possible meaning, effectiveness and developmental perspectives of EWCs have been put forward, with mainly sceptical views predominating. On the one hand, Streeck (1997) criticises the lack of regulatory power of EWCs, arguing that it lags far behind the regulatory power made possible by the German model of employee participation. On the other hand, he criticises the deficient link between the EWC institution and Europe. He considers EWCs to be mainly extensions of the lobbies of the respective headquarters' home country, whose structural principles and modes of operation are conveyed to other parts of the company via the EWC. In this spirit EWCs are (dis)qualified as 'neither European nor works councils' (Streeck 1997: 328). In view of the danger of 'social dumping', the EWC as an employees' committee is 
not an appropriate instrument, neither in intra-company, nor in cross-country competition (Keller 2001). Location competition has further intensified since 1996 and 'EWCs have failed to become a pan-European vehicle for trade union coordination' (Hancké 2000: 55).

According to some scientists close to labour unions there is a 'danger of a European neosyndicalism' (Schulten 1997: 97). EWCs are viewed critically especially because they present themselves as potential partners for collective contracts, and therefore directly compete with labour unions as national or even pan-European wage bargaining partners. This argument claims that the increase in company-related regulation of tariff matters on a European level might lead international companies to withdraw from national contract relations, thereby additionally accelerating the tendency toward erosion currently displayed by the national bargaining systems. Another point of criticism is the voluntarism regarding the concrete form of EWCs. The 'political effectiveness' of an EWC accordingly depends on the (single) company's power relations and the backing of labour unions (Schulten 1999: 201).

Optimistic views, in contrast, emphasize the evolutionary dynamic of EWCs which must still be considered as a 'search and orientation process' (Platzer and Rüb 1999). These accounts argue that the behaviour of some EWCs clearly surpass the degree of participation provided for by the directive, and that this should lead to positive effects for the European and national systems of labour relations (ibid).

The very nature of EWCs is quite unique in the world and in the landscape of European organisations because they are effectively (1) European law-based non-profit organisations, (2) based on the different national transposition laws of the countries where the corresponding companies are active, (3) working on the basis of an agreement negotiated at the European level between management and labour representatives, and (4) directed towards Europe-wide active companies as profit organisations embedded exclusively in the corresponding national law systems. At first glance due to this complex national, supranational and company level organisational network, EWCs are a promising answer to the problem of interest regulation in times of increasing economic internationalisation.

But EWCs are not only very interesting and particular in organisational and institutional terms - they are also very important in practice. Despite the fact that only about one third of all companies falling under the EWC directive actually have a EWC, their significance and impact upon labour regulation at the European level should not be underestimated. When the European Union consisted of fifteen member states EWCs represented a total of about 17 million people (Hertwig et al 2010). Taking into consideration the new EU member states, the number of people receiving direct representation is even higher. As EWC coverage increases both with the number of employees and the number of countries in the EEA the companies are active in, almost two third of all workers and employees engaged in companies that are active Europe wide are currently represented by aWC.

Therefore, it is not surprising that there is a broad stream of scientific research and debate about EWCs. The European automobile industry is of crucial interest, first, due to the high concentration of companies falling under the directive and, second, because of the significance of some explicit debates and conflicts which touched the European level of labour regulation (like the General Motors case or the Volkswagen-Porsche conflict). Scientific debate on EWCs concentrates on the character, function and reach of the EWC. Is this new Europe wide active body an unsuitable instrument to cope with economic internationalisation? Will it mainly 
function as an information and communication channel for management? Or can it develop to be a powerful and effective means of organising and expressing worker interests at a supranational level? Are the EWCs just mere extensions of labour regulation patterns and dynamics of the country where a company's headquarters are located? Or can they actually introduce a genuine European dimension to labour relations and a new logic of transnational labour negotiations?

Empirical research seeking to answer these questions is focused mainly on two issues. First, it seeks to develop an adequate typology of EWCs (based on their internal structure and pluri-local plant relations as well as their relations to management and unions) and, second, it seeks to control for variables (like sector, age of the EWC, country of company's headquarters) influencing these types of EWCs and their corresponding output and efficiency as a means of interest mediation and conflict regulation. There is some empirical evidence of the impact of (1) country of headquarters, (2) sector characteristics and (3) periods of negotiating and signing the EWC agreements on the figures and outcome of EWC's working dynamics. Until now, little attention has been paid to the impact of company structures on the corresponding structures and activities of EWCs. However, previous studies have pointed out that there is a wide degree of variance amongst EWCs regarding their activities and their ability to effectively influence company decisions and represent employee interests. While some EWCs operate on a low level (as simple 'tools' for the distribution of selected management information), others play an important role in the overall communication and interest regulation of the company at the European level. To explain these variations in EWC cooperation structures and characteristics, the majority of literature is based on an (extended) industrial relations approach. This dominant research perspective on EWCs could be widened by an organization-based research approach. It could be proven that one has to pay special attention to the specific figure of distribution and coordination of resources, power, culture, and knowledge at the European company level (Hertwig, Pries and Rampeltshammer 2010). In this perspective, the organizational fit between the cross-border company structure and the structure of the corresponding EWC at least partly explains its output. In this way EWCs could be considered as tools for re-embedding cross-border active companies within a supranational framework of labour regulation. When, apart from this, EWCs are also crucial cross-border actors for developing European or International Framework Agreements - as was shown for example by Dehnen and Pries (2012) - the entanglement of different mechanisms and logics of cross-border labour regulation becomes obvious.

When trying to understand the phenomenon of EWCs within a broader context, a strong entanglement within the multidimensional network texture introduced above becomes apparent. First, European legislation provides a framework in which EWCs (if demanded by the employees) become a mandatory element of company structures. Second, cooperation between local or national unions and/or international union federations is crucial for bonding and capacity development in EWCs. Third, as shown by empirical research in the automotive sector, an assessment of an EWC and a comparison of different EWCs is hardly possible when considering only the number of formal agreements signed, the resolutions passed or the strike activities initiated; the situational and institutional context of company structures and cultures must also be addressed (Hertwig, Pries and Rampeltshammer 2011: 223).

A further interconnection, which will be highlighted in the next paragraph, refers to EWC's involvement with global company-wide measures of labour regulation, such as international framework agreements. 


\section{INTERNATIONAL FRAMEWORK AGREEMENTS}

Since the first application of International Framework Agreements in the late 1980s a broad body of literature has emerged that treats IFAs as an innovative form of cross-border labour regulation. ${ }^{8}$ According to a general definition proposed by Fichter, Helfen and Sydow (2011), IFAs can be understood as 'a tool for enforcing the recognition and implementation of minimum labour standards and as a contract between unions and transnational corporations'. Through their implementation, the actors involved (usually management and internal company worker representatives as well as international unions) pursue four different and often complementary goals (see ibid): (1) ensuring compliance with the ILO's core labour standards, (2) recognition of the Global Union Federation as a negotiation partner, (3) global institutionalization of viable collective conflict resolution mechanisms, and (4) the organization of transnational solidarity.

In December of 2010, over 80 IFAs existed, involving a total of 6.3 million of the 77 million workers employed in multinational companies on a global scale (Papadakis 2011). ${ }^{9}$ While this is only a small portion of the entire workforce employed in MNCs, the last twenty years have seen significant numerical development for IFAs. While only 23 IFAs existed in the period between 1988 and 2002, by 2007 there were 56 (ibid), most of which were signed in the metal sector. As can be derived from the general description of IFAs as a social phenomenon and their role in shaping the reality of cross-border labour regulation given above, the instrument - as in the case of the European works councils - is mainly focused on the company level. However, as the involvement of various groups (unions, shop-floor organs, management actors) illustrate, their particular dynamics cannot be simply reduced to one-sided intentions and ambitions. Instead, functional international agreements require cooperation between all actors introduced. As Rüb et al (2011: 21) point out, a low degree of organizational and informational networking between unions and shop floor representatives raises the probability of taking actual influence on policy measures within the framework of a particular MNC. Although the central measures addressed through IFAs relate to intra-company issues, attempts to transcend the 'shop-floor-focus' of the instrument can also be found. In a document analysis carried out in late 2008, Welt (2011: 54) finds that 46 percent of existing IFAs inform suppliers and encourage them to adhere to the content of the IFA. Moreover, 14 percent take measures to assure supplier compliance and another 9 percent even assume responsibility for the entire supply chain. Another significant element that constitutes the particularly relational character of IFAs as instruments of crossborder labour regulation is the designated reference, which is given to comprehensive standards as the ILO-norms or CSR-approaches such as the United Nations Global Compact: "What distinguishes IFAs as a policy tool beyond their labour relations character is their acknowledgement of CSR approaches, such as the United Nations Global Compact or the Organization for Economic Co-operation and Development Guidelines' (Fichter and Helfen 2011: 86). This very same conclusion can also be drawn from a finding provided by Thomas (2010: 11): 'Some companies with framework agreements [...] may engage in third party monitoring processes through their broader CSR programs, though framework agreements do not establish these kinds of processes themselves'.

The value-based reference points of IFAs by no means plainly emerge from intra-company negotiations or dispositions, but instead function in close relation with a global moral framework constituted by multipartite actors, such as the International Labour Organization, or even within broader discursive arenas. 
It is not surprising that the constellation within which an International Framework Agreement gains its shape and meaning presupposes the existence and involvement of relatively strong organs of worker representation. These can both be located at the company and broader union level. For Hennebert and Bourque (2011: 158) global union federations:

'are at the junction of complex social and political interactions in which they are only one actor. Their role must thus be conceived in relation to other local, national and regional levels where union organizations have historically been rooted and, at times, endowed with substantial resources'.

In their seminal work on global unions, Platzer and Müller (2009) point out how crucial these federations are for the cross-border coordination of worker representatives. However, recent empirical developments have also shown the central role that shop-floor representation can take on in the development of such framework agreements. Here, for example the Volkswagen Works Council takes a leading role. A step toward a new level of worker participation in cross-border contexts could be taken by Volkswagen management and the International Metalworkers Federation jointly signing an IFA on the international implementation of co-determination measures in all countries, represented within the World Works Council. (Wannöffel 2010; Baum-Ceisig and Osterloh 2011).

Interest is IFAs is no longer confined to worker representatives at the level of the local shop-floor, national, or even international level. Nor is it only of interest to civil society actors engaging in NGO initiatives, such as the Clean Clothes Campaign. A general interest in International Framework Agreements can also be seen to come from the side of management:

'In line with the GUF's main objective of establishing an ongoing dialogue with transnational companies through the conclusion of an IFA, the GUFs usually try to settle any violation of the provisions of an IFA in cooperation with management. (Welt 2011: 58)

Due to the Marxist inheritance of industrial sociology, capital-labour relations are often described as genuinely conflictual, and yet the coordination of IFA-measures relies on cooperation between the two groups of actors which might lead to a blurring of the traditionally perceived demarcation line. Interestingly, this conceptual argument can also be supported by a study conducted by the ILO which states that management can take an interest in engaging in International Framework Agreements. This general assumption is based on the finding that an increased trust in labour relations at the company level can be found amongst shareholders and other investors (ILO 2010).

While the ILO study introduced above measures the impact on shareholder trust in companies, management actors could moreover generally be assumed to be interested in maintaining a proper image for customers and stakeholders. This is where one of four points of critique with regards to such framework agreements can be formulated. While firstly the regulation of core labour standards can be said to be generally desirable, it is important to note that a simple window-dressing approach pursued by management will not help to bring about sustainable measures in the mid-to-long term. While an IFA might make sense as an idea or 
sound suitable as a rhetorical figure, its implementation must be actually carried out for it to take effect. Secondly, the integration of global union federations is crucial for the coordination of IFAs in a cross-border context. What must also be clear is that this may require major engagements which may overstretch scarce resources. A third potentially weak point is the generally voluntary nature of IFAs. As Thomas (2010: 15) notes, a stronger foundation within supranational legislation might seem desirable in this context, as 'transnational labour rights regulatory strategies must move beyond binary approaches to regulation based on state-based versus voluntaristic, privatized methods'.

A fourth open question finally points at the inclusive character of International Framework Agreements. While IFAs generally help to create acceptance for measures suitable to de-commodification of the character of wage-labour on a global level, one must acknowledge the fact that they do not yet address the major share of workers who are integrated in global production chains. One might thus perceive the danger of IFAs leading to the privileging of strongly unionized workers in international original equipment manufacturers or first-tiersuppliers, leaving out all those who are unable to organize sufficiently. A strong trade unionism alone cannot be the only answer for the sustainable regulation of international labour.

'In sum, IFAs are the most participative category and also the one closest to a traditional understanding of industrial relations - in the sense of negotiation, consultation or simply exchange of information between employers and workers on issues of common interest relating to socio-economic policy - and to the notions of collective bargaining, dispute prevention and resolution, as well as respect for labour law'. (Papadakis 2011:3)

It thus can be concluded that International Framework Agreements open certain opportunities and challenges for cross-border labour regulation. What seems important to note is that they gain their particular significance not in isolation from other measures taken in this sense, but are to be understood in a close interrelationship with the broad portfolio of crossborder regulation initiatives. A first obvious interconnection can be found in the fact that company-level regulation in the form of an IFA is often a measure complementary to or promoted by a company-level body of labour regulation, such as a European or even World Works Council. Moreover, as is e.g. noted by Fichter et al (2011a: 602), IFAs are strategically sought after and used by Global Union Federations aiming to secure their own acceptance and using organizing potential that exists on the local level to achieve recognition of the ILO's core labour standards. In this explicit reference to the comprehensive framework provided by the ILO lies a third important example for the structuring power of the cross-border network texture.

Having presented the two examples of European Works Councils and International Framework Agreements within their particular contexts of (international) labour regulation, now the potentials, challenges and limitations of the emerging cross-border network texture will finally be discussed. 


\section{Re-Embedding the Global Market?}

Although economic globalisation represents a kind of dis-embedding of markets and value chains from the exclusive control of nation states and from the national settings of institutional arrangements such as labour regulation, counteracting mechanisms of re-embedding also exists which also contribute to emerging textures of transnational labour regulation. Global minimum standards for work and employment conditions as defined by the ILO, the integration of national and regional union confederations in a Global Union Federation, the mechanism of imposing the OECD multinational guidelines on companies active in cross-border contexts, the foundation of World Works Councils in some important sites controlled by global players, transnational labelling and branding strategies such as 'Fair Trade' or 'Decent Work' as well as EWCs and International Framework Agreements are ties that form part of an emerging transnational texture of labour regulation that increasingly enmeshes and re-embeds the globalised economy.

There could be a myriad of examples and arguments cited that make claims against the efficiency of each of these mechanisms and against interpreting a transnational texture of labour regulation. When looking at any one of the mechanisms that has been mentioned in an isolated manner there always could be doubt: ILO minimum standards do not work when there is no collective actor or sensitive public opinion, for example, and this is just the case where they would be needed. OECD multinational guidelines are almost unknown and do not work in many companies. EWCs are often weak in comparison to local or national representation bodies, like shop stewards or Works Councils. International Framework Agreements have no legally binding power of enforcement.

However, by taking a closer look at how these different cross-border threats could be combined and intertwined, the emerging transnational texture of labour regulation actually gains more and more contours. The example of International Framework Agreements that was mentioned illustrates this point quite well: when viewed in isolation of details of concrete implementation and monitoring, the ILO-core norms (or the content of IFAs in general) can - in many cases and with good reason - be considered to be little more than an open invitation to humanist window dressing. What constitutes the dynamics of the network texture in this context is the interplay of a normative framework for political processes of labour regulation. As Walby (2011: 141) notes, "Human Rights" do not form a theory of how society functions, they are merely a list of goals'. If, however, these goals become embedded in the framework of a legitimate symbolic corporate actor (as in the case of the ILO), they can be referred to and used as tools by political agencies and other collective actors to improve conditions of work, employment and participation at the (shop-floor-) level of every life-world. ${ }^{10}$

Therefore, the argument developed in this paper is that any given single element of the network texture can only be understood in relation to every other element. To pick single measures out of this network texture ${ }^{11}$ would be akin to attempting to watch a football match by focusing on only one of the twenty-two players. Rejecting such a narrow focus allows a more fruitful attempt to understand the dynamics of the internationalization of labour regulation as an emerging network texture. The idea of a transnational network texture (as well as the empirical findings supporting it) invites a strengthening of the sociological perspective of international labour relations and a relational approach which sees actors neither as principally isolated units (Sitkin and Bowen 2010), nor as phenomena which are simply brought about by purely structural conditions (Meyer et al 1997). 
Viewed from a methodological perspective, the implications for conceptualizing research on international labour regulation become apparent. Since a significant amount of academic reflection about cross-border phenomena is based on research built around case studies, the question arises of the extent to which the focus on single issues already contains a starting point for a bias against our argument. As argued by various scholars (Burawoy 2009a; Marcus 1995), a narrow view on (seemingly) isolated phenomena often cannot capture the social preconditions and consequences of these phenomena.

If one looks at the current debate on global governance, various problems and challenges are being addresses with regards to the democratic legitimacy of an international governance system, which is said to privilege decision-making processes in a top-down manner. Here, Krajewski (2009) points to three aspects which he perceives to be potentially problematic. First, decision-making on a global scale is practically taking place among representatives of only a few states. What's more, since these decisions are made by a select few representatives and experts, the actual populations of the countries involved does not really have a voice in the committees. Thirdly, Krajewski perceives these negotiations to lack a complementary societal discourse with actual deliberative potential in terms of dealing with questions of international economic governance. Since the design of international organizations such as the European Union does not exactly favour bottom-up-initiatives, it now seems reasonable to ask whether the emerging texture of cross-border labour regulations can take the place of such a bottom-up approach. By giving a conceptual overview of the cross-border network texture of labour regulation as a structure that is growing more and more dense in the course of the internationalisation of worker representatives, one obviously also has to acknowledge that there are difficulties and challenges which have to be met by the initiatives engaging in this process. ${ }^{12}$ While thus perceiving a lot of coordination work to be done between representatives of workers, management, states and civil society, there seems to appear no alternative to this complex process of re-embedding the economy in society by such an emerging texture of transnational labour regulation.

\section{NOTES}

1. For more on the protagonist role of the United States in global processes of neo-liberal economic modernization also see Kaufmann (2006: 152). It is questionable, whether the USA, the United Kingdom or other international actors like the International Monetary Fund with its debt restructuring programs after the so-called oil crisis were the decisive driving force of this turn towards liberal market strategies. Furthermore, as Minssen (2012: 178) points out correctly, it would be far-fetched to speak of a neoliberal project in the sense of a well-planned procedure, intentionally carried out by concrete identifiable actors. As social macro-processes which, among other things, lead to a reconfiguration of labour regulation are governable only to a slight degree, such general assertions can be suspected of actually belonging in the field of conspiracy theory.

2. Differences however remain with regards to the varying degrees of world-market integration which scholars assume for particular countries and macro-regions. While the major share of 
international trade in the last quarter of the $21^{\text {st }}$ century has mainly taken place within the triad of North America, Europe and Japan, the current debate around the BRICs (Brazil, Russia, India and China, sometimes also countries like Mexico or South Africa) effectively illustrates this point.

3. In so far as not every type of labour can be bought and sold anywhere on the globe, this is obviously an exaggeration. However, the increasing cross-border mobility of productive organizations towards cheap and adequate labour (internationalization of value chains) and of labour towards employment opportunities (internationalization of labour migration) constitutes a significant tendency for the analysis of economic developments. Accordingly, human and capital mobility have become structural characteristics of the world economy (see Pries 2010a for the case of labour migration).

4. Interestingly, the emergence and development of this movie-genre within the Anglo-American context can be traced back as developing in parallel with increasing liberalization in politics under the influence of Reaganomics and Thatcherism in the frame of the Washington Consensus. Ecological devastation, political anomy and a collective exhaustion as well as the constant thread of apocalypse serve as an allegory for the danger of a decline of civilization. It does not take a lot of fantasy to interpret this as a popular anticipation of the possible risks and dangers of neoliberal modernization.

5. Great Britain made use of its ability to opt-out and withdrew from the entire process only to join the EWC plan after Labour's electoral victory in 1997.

6. As an alternative to a EWC the directive offers the option of defining a procedure of information and consultation.

7. For general information on EWCs see the EWC database (also available as a CD-ROM) at http://www.etuirehs.org/workers_participation/projects/european_works_councils_database_1.f.

8. See for example Thomas (2010); Fichter et al. (2011, 2011a); Papadakis (2011); Rüb et al (2011).

9. This number does not include suppliers and sub-contractors.

10. Moreover, the same sceptical arguments against the single mechanisms could also be made for the national level - there are many collective bargaining agreements which, although legally binding, have not had such strong regulatory power.

11. As for example Streeck (1997) does with regards to the perspectives of European Works Councils.

12. As is known from research on cross-border governance mechanisms or the emergence of structures perceived as e.g. 'transnational communities' (Djelic and Quack 2010), a core problem lies in the establishment of trust relations between the actors involved. Since such constellations 
in an international context consists of actors, who are drawing on different institutional conditions (e.g. welfare-state-structures) or cultural background (e.g. stocks of knowledge among themselves and their local reference groups), coordination efforts arising in this context comprise - on the other hand - challenges beyond most experiences, traditionally made on a national level (Hall and Soskice 2001; Frege and Kelly 2004).

\section{REFERENCES}

Altvater, E. and Mahnkopf, B. (1997) 'The World Market Unbound', Review of International Political Economy 4(3): 448-471.

Balsiger, Philip (2010) 'Making Political Consumers: The Tactical Action Repertoire of a Campaign for Clean Clothes', Social Movement Studies 9(3): 311-329.

Baum-Ceisig, A. and Osterloh, B. (2011) 'Wirtschaftsdemokratie in der Praxis - Die erweiterte Mitbestimmung bei Volkswagen', in Meine, H.(ed), Mehr Wirtschaftsdemokratie wagen! (pp. 123-139). Hamburg: VSA.

Burawoy, M. (2009) 'The Global Turn. Lessons From Southern Labour Scholars and The Labor Movement', Work and Occupations 36(2): 87-95.

Burawoy, M. (2009a) Extended Case Method: Four Countries, Four Decades, Four Great Transformations, and One Theoretical Tradition. Berkeley: University of California Press.

Burawoy, M. (2010) 'From Polanyi to Pollyanna: The False Optimism of Global Labour Studies', Global Labour Journal 1(2): 300-313.

Baumann, Z. (2000) Liquid Modernity. London: Blackwell.

Beck, U. (1999) World Risk Society. London: Blackwell.

Cohen, R. and Kennedy, P. (2000) Global Sociology. New York: New York University Press.

Dehnen, V. and Pries, L. (2012) 'International Framework Agreements: Window-Dressing for Trade Unions or Efficient Instrument of Cross-Border Labour Regulation?' (forthcoming in Industrial Relations Journal).

Dewey, J. (1922) Human Nature and Conduct: An Introduction to Social Psychology. New York: Modern Library. 
Djelic, L. and Quack, S. (2010) Transnational Communities. Shaping Global Economic Governance. Cambridge: University Press.

Durkheim, E. (1984) The Division of Labour in Society. London: Macmillan.

Egels-Zanden, N. (2009) 'Transnational Governance of Workers Rights: Outlining a Research Agenda', Journal of Business Ethics 87(2): 169-188.

Fichter, M. and Helfen, M. (2011) 'Going Local with Global Policies. Implementing International Framework Agreements in Brazil and the Unites States', in K. Papadakis (ed) Shaping Global Industrial Relations. The Impact of International Framework Agreements (pp. 85-115). New York: Palgrave Macmillan.

Fichter, M., Helfen, M. and Sydow, J. (2011) 'Regulating Labour Relations in Global Production Networks', IPG 2:69-86.

Fichter, M.; Helfen, M. and Sydow, J. (2011a) 'Employment Relations in Global Production Networks', Human Relations 64(4): 599-622.

Frege, C. and Kelly, J. (2004) Varieties of Unionism. Oxford: University Press.

Hann, C. and Hart, K. (eds) (2009) Market and Society: The Great Transformation Today. New York: Cambridge University Press.

Hennebert, M.A. and Bourque, R. (2011) 'The International Trade Union Confederation (ITUC): Insights from the Second World Congress', Global Labour Journal 2(2): 154159.

Hertwig, M., Pries, L. and Rampeltshammer, L. (eds) (2010) European Works Councils in Complementary Perspectives. Brussels: ETUI.

Hertwig, M., Pries, L. and Rampeltshammer, L. (2011) 'Stabilizing Effects of Cross-Border Institutions. The Case of the European Works Councils', European Journal of Industrial Relations 17(3): 209-226.

International Labour Organization (2010) 'Assessing the Social Impact of IFAs: An ILO Online Survey (2008-2009)'. Available at: http://lempnet.itcilo.org/en/tcas/abouttcas/background-papers/ifa-survey-2008-09.pdf. (Accessed 30 July 2012).

Joas, H. (1997) The Creativity of Action. Chicago: Chicago University Press.

Koch-Baumgarten, S. (2006) 'Globale Gewerkschaften und Industrielle Beziehungen in der Global Governance’, Industrielle Beziehungen 13(3): 205-222. 
Kaufmann, B. E. (2006) Global Industrial Relations. Events, Ideas and the IIRA. Geneva: ILO.

Krajewski, M. (2009) 'Die Demokratisierung von Global Economic Governance', in H. Brunkhorst (ed), Demokratie in der Weltgesellschaft. Sonderband 18 Soziale Welt. BadenBaden: Nomos.

Lambert, Rob (2010) 'Unionism in One Country is no Longer an Option. A Response to Michael Burawoy's "From Polanyi to Pollyanna: The False Optimism of Global Labour Studies” (GLJ 1.2)', Global Labour Journal 1(3): 388-392.

Marcus, G.E. (1995) 'Ethnography in/of the World System', Annual Review of Anthropology 24: 95-117.

Marx, K. and Engels, F. (1848) 'The Communist Manifesto', in N.H. Barma and S.K. Vogel (eds) (2007), The Political Economy Reader. New York: Routledge.

Mead, G. H. (1967) Mind, Self, and Society: From the Standpoint of a Social Behaviorist. Chicago: University of Chicago Press.

Meyer, J.W., Gili, S., Drori, F.O. Ramirez, and Schofer, E. (2003) Science in the Modern World Polity: Institutionalization and Globalization. Stanford: Stanford University Press.

Meyer, J.W. and Rowan, B. (1977) 'Institutionalized Organizations: Formal Structure as Myth and Ceremony', American Journal of Sociology 83(2): 340 - 363.

Meyer, J. et al. (1997) 'World Society and the Nation-State', American Journal of Sociology 103(1): 144-81.

Minssen, H. (2012) Arbeit in der modernen Gesellschaft. Wiesbaden: VS-Verlag.

OECD (2008) OECD Guidelines for Multinational Enterprises. Paris: OECD.

OECD Watch (2012) The OECD Guidelines for Multinational Enterprises. A Tool for Responsible Business Conduct. Amsterdam: OECD Watch.

Papadakis, K. (2011) 'Introduction and Overview', in Papadakis, K. (ed) Shaping Global Industrial Relations. The Impact of International Framework Agreements (pp. 1-18). New York: Palgrave Macmillan.

Platzer, H.-W. and Müller, T. (2009) Die globalen und europäischen Gewerkschaftsverbände. Berlin: Sigma.

Polanyi, K. (1957) The Great Transformation. Boston: Beacon Press. 
Powell, W.W. and DiMaggio, P.J. (eds) (1991) The New Institutionalism in Organizational Analysis. Chicago: University of Chicago Press.

Pries, L. and Dehnen, V. (2009) 'Location Tendencies of the International Automotive Industry', International Journal of Automotive Technology and Management 9(4): 415-437.

Pries, L. (2010) Erwerbsregulierung in einer globalisierten Welt. Wiesbaden: VS-Verlag.

Pries, L. (2010) 'Internationalisierung von Arbeitsmobilität durch Arbeitsmigration', in Böhle, F. et al. (eds) Handbuch Arbeitssoziologie (pp. 729-747). Wiesbaden: VS-Verlag.

Pries, L. and Seeliger, M. (2012) 'Transnational Social Spaces Between Methodological Nationalism and "Cosmo-Globalism", in A. Amelina, N. Devrimsel, T. Faist and N. Glick Schiller (eds) Beyond Methodological Nationalism: Social Science Research Methodologies in Transition (pp. 219-238). London/New York: Routledge.

Ruigrok, W. and van Tulder, R. (1995) The Logic of International Restructuring. London/New York: Routledge.

Rüb, T. (2009) Die Transnationalisierung der Gewerkschaften. Berlin: Sigma.

Rüb, T. et al. (2011) Transnationale Unternehmensvereinbarungen. Berlin: Sigma.

Seidmann, G. (2007) Beyond the Boycott: Labour Rights, Human Rights and Transnational Activism. New York City: Russell Sage Foundation.

Simmel, G. (1972) On Individuality and Social Forms. Chicago: University of Chicago Press.

Sitkin, A. and Bowen, N. (2010) International Business. Challenges and Choices. Oxford: Oxford University Press.

Spatz, J. and P. Nunnenkamp (2002) 'Globalization of the Automobile Industry: Traditional Locations Under Pressure?’, Außenwirtschaft 57(4): 469-493.

Streeck, W. (1997) 'Neither European Nor Works Councils: A Reply to Paul Knutsen', Economic and Industrial Democracy 18(2): 325-337.

Sturgeon, T.J., and Florida, R.L. (1999) The World That Changed the Machine: Globalization and Jobs in the Automotive Industry. Cambridge: MA.

Telljohan, V. (2009) European and International Framework Agreements: Practical Experiences and Strategic Approaches. Dublin: European Foundation for the Improvement of Living and Working Conditions. 
Thomas, M. P. (2010) 'Global Industrial Relations? Framework Agreements and the Regulation of International Labour Standards', Labour Studies Journal 10(2): 1-19.

Tilly, C. (1995) 'Globalization Threatens Labour's Rights', Journal of International Labour and Working Class History 47(1): 1-23.

Walby, S. (2011) The Future of Feminism. Cambridge: Polity Press.

Wannöffel, M. (2011) 'Auch für „Old Opel“ gilt: Europäische oder keine Lösung', in Gerlach, T. et al. (eds) Solidarität über Grenzen (pp. 95-108). Berlin: Sigma.

Weber, M. (2001) The Protestant Ethic and 'The Spirit of Capitalism'. Oxford: Oxford University Press.

Webster, E. (2010) 'From Critical Sociology to Combat Sport? A Response to Michael Burawoy's "From Polanyi to Pollyanna: The False Optimism of Global Labour Studies", Global Labour Journal 1(3): 382-387.

Webster, E., Lambert, R. and Bezuidenhout, V. (2008) Grounding Globalization. Labour in the Age of Insecurity. Oxford: Blackwell.

Wells, D. (2009) 'Local Worker Struggles in the Global south: Reconsidering Northern Impacts on International Labour Standards', Third World Quarterly 30(3): 567-579.

White, H.C. (1992) Identity and Control: A Structural Theory of Social Action. Princeton: Princeton University Press.

Whitley, R. (1992) 'The Comparative Study of Business Systems in Europe: Issues and Choices', in Whitley, R. (ed), European Business Systems. Firms and Markets in their National Contexts. London: Sage Publications.

Zajak, S. (2009) 'Polanyi, Labor Activism and Transnational Governance Structures: The Role of “The Counter Movement" In Two Different Industry Fields', in 'Shaping Europe in a Globalized World? Protest Movements and the Rise of a Transnational Civil Society', Marie Curie Conference Reader, University of Zürich.

\section{BIOGRAPHICAL NOTE}

LUDGER PRIES holds a Chair for Sociology at Ruhr-Universität Bochum. He taught and did research in Brazil, Mexico, Spain and the USA. He was visiting fellow at Universidade Federale de Minas Geráis/Belo Horizonte, Universidad Autónoma Metropolitana and El Colegio de 
Mexico/Mexico-City, University of Pennsylvania/Philadelphia, Cornell University/Ithaca and Columbia University/New York. Main fields of research interest include: Sociology of Organisations, Work and Labour Regulation, and migration in international comparison, especially transnationalisation, transnational migration and processes of social incorporation. [email: ludger.pries@rub.de]

MARTIN SEELIGER has worked at the Ruhr-University of Bochum as a researcher and is currently a PhD-Student at the Max-Planck Institute for the Study of Societies in Cologne. His research interests include cross-border labour relations, organization studies and sociological theory. He was a visiting fellow at the Sociology Department of the Universidad Autónoma Metropolitana, Mexico City from February to April 2012 and has collected international fieldwork experience in Mexico and South Africa. [e-mail: martin.seeliger@gmx.net] 